\title{
Diversity matters in scientific publishing
}

\author{
Kuan-Teh Jeang
}

\section{Abstract \\ The importance of geographic diversity in publishing is emphasized in this editorial.}

Earlier this year, I read about a remarkable change in the United States population. For the first time in United States history, the majority (50.4\%) of children 1 year and younger are from minority groups (e.g. Hispanic American, African American, Asian American etc... .). In fact, the face of America is changing not just amongst her young but in its totality. Population projections show by the year 2043, the United States population will exceed 400 million; and minority groups will compose a majority of this number. Already four states in the United States (Texas, California, Hawaii, and New Mexico) are "majority-minority" states where the combined population of various "minorities" exceeds the erstwhile "white majority" number.

The face of global science is also changing. I have previously written about the rise of bioscience in the East [1]. A Royal Society report (http://royalsociety.org/policy/ projects/knowledge-networks-nations/report/), surveying the knowledge, networks and nations landscape in 2011, confirmed this notion and projected that by 2013 the total number of scientific publications from China published in English will overtake the counterpart number from the United States. Anecdotally, in recent years each of us has seen a steady increase in the number of papers published in our leading biomedical journals by Chinese and Asian authors. Surprisingly, in the face of these trends, a longstanding publishing inherency appears to hold sway. Thus, last year in a newsletter to its editors, the largest publisher of biomedical literature Elsevier reported that "while the spread of countries represented on the editorial boards of Elsevier journals is 'reasonable', countries such as India and China are under-represented in comparison with their share of published articles. Interestingly, the percentage of Elsevier editors from China is $3.3 \%$ while nearly $13 \%$ of published articles originate there. Some countries are also significantly over-represented, for example, $40 \%$ of our

Correspondence: kjeang@nih.gov

The National Institutes of Health, Bethesda, MD, USA editors come from the US while only $18 \%$ of published articles originate there..." Needless to say, this imbalance should be remedied.

In this regard, how is the editorial diversity at Retrovirology? Amongst the 8 Retrovirology editors, 6 are from countries outside of North America (a 75\% non-North American representation). In Retrovirology's 60 member editorial board, 32 individuals hail from outside of North America (a 53\% majority). We believe that diversity is important because we hold firm the idea that intelligence and ambition are distributed equally around the globe [2]. One area that we need to do better is to publish more papers from authors outside of the traditional bastions of North American and West European science. In examining all papers published last year, I found that only 10 published Retrovirology papers came from authors based outside of North America and Western Europe [3-12]; and these papers were submitted from either Australia or Japan. Although peer-reviewed quality remains the criterion for publication, our goal is to strongly encourage and work hard in attracting to Retrovirology more manuscripts from diverse areas of the world. Diversity in science and scientific publishing matters.

\section{Acknowledgements \\ The opinions expressed in this editorial represent KTJ's personal views and do not necessary reflect the views of his employer, the National Institutes of Health, USA. Research performed in KTJ's laboratory is supported by intramural funds from the NIAID, NIH. The author thanks Mark Wainberg and Andrew Dayton for reading this editorial.}

Received: 17 December 2012 Accepted: 18 December 2012 Published: 19 December 2012

\section{References}

1. Jeang KT: The rise of bioscience in the East. Retrovirology 2010, 7:106

2. Jeang KT: Intelligence and ambition are distributed equally around the globe. Retrovirology 2010, 7:67.

3. Wu JQ, Dwyer DE, Dyer WB, Yang YH, Wang B, Saksena NK: Genome-wide analysis of primary CD4+ and CD8+ $T$ cell transcriptomes shows evidence for a network of enriched pathways associated with HIV disease. Retrovirology 2011, 8:18.

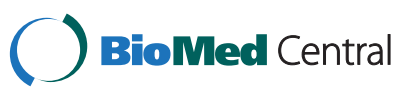


4. Hagiya K, Yasunaga J, Satou Y, Ohshima K, Matsuoka M: ATF3, an HTLV-1 bZip factor binding protein, promotes proliferation of adult T-cell leukemia cells. Retrovirology 2011, 8:19.

5. Furuta RA, Miyazawa T, Sugiyama T, Kuratsune H, Ikeda Y, Sato E, et al: No association of xenotropic murine leukemia virus-related virus with prostate cancer or chronic fatigue syndrome in Japan. Retrovirology 2011, 8:20

6. Gray L, Sterjovski J, Ramsland PA, Churchill MJ, Gorry PR: Conformational alterations in the CD4 binding cavity of HIV-1 gp120 influencing gp120-CD4 interactions and fusogenicity of HIV-1 envelopes derived from brain and other tissues. Retrovirology 2011, 8:42.

7. Saleh S, Wightman F, Ramanayake S, Alexander M, Kumar N, Khoury G, et al: Expression and reactivation of HIV in a chemokine induced model of HIV latency in primary resting CD4+ T cells. Retrovirology 2011, 8:80.

8. Mwimanzi P, Hasan Z, Hassan R, Suzu S, Takiguchi M, Ueno T: Effects of naturally-arising HIV Nef mutations on cytotoxic T lymphocyte recognition and Nef's functionality in primary macrophages. Retrovirology 2011, 8:50.

9. Roche M, Jakobsen MR, Ellett A, Salimiseyedabad H, Jubb B, Westby M, et al: HIV-1 predisposed to acquiring resistance to maraviroc (MVC) and other CCR5 antagonists in vitro has an inherent, low-level ability to utilize MVC-bound CCR5 for entry. Retrovirology 2011, 8:89.

10. Adachi T, Tanaka R, Kodama A, Saito M, Takahashi Y, Ansari AA, et al Identification of an unique CXCR4 epitope whose ligation inhibits infection by both CXCR4 and CCR5 tropic human immunodeficiency type-I viruses. Retrovirology 2011, 8:84.

11. Evans VA, Lal L, Akkina R, Solomon A, Wright E, Lewin SR, et al: Thymic plasmacytoid dendritic cells are susceptible to productive HIV-1 infection and efficiently transfer R5 HIV-1 to thymocytes in vitro. Retrovirology 2011, 8:43.

12. Takamori A, Hasegawa A, Utsunomiya A, Maeda Y, Yamano Y, Masuda M, et al: Functional impairment of Tax-specific but not cytomegalovirus-specific CD8+ T lymphocytes in a minor population of asymptomatic human T-cell leukemia virus type 1-carriers. Retrovirology 2011, 8:100.

doi:10.1186/1742-4690-9-109

Cite this article as: Jeang: Diversity matters in scientific publishing. Retrovirology 2012 9:109.

\section{Submit your next manuscript to BioMed Central and take full advantage of:}

- Convenient online submission

- Thorough peer review

- No space constraints or color figure charges

- Immediate publication on acceptance

- Inclusion in PubMed, CAS, Scopus and Google Scholar

- Research which is freely available for redistribution 